\title{
THE POSITION AND STRUCTURE OF THE NECTARY IN SPRING HEATH (Erica carnea L.) FLOWERS
}

\author{
Elżbieta Weryszko-Chmielewska ${ }^{1}$, Mirosława Chwil ${ }^{1}$, Marek Wróbel ${ }^{2}$ \\ ${ }^{1}$ Department of Botany, University of Life Sciences in Lublin, 20-950 Lublin, Akademicka 15, Poland, \\ e-mail: elzbieta.weryszko@up.lublin.pl \\ ${ }^{2}$ Central Apparatus Laboratory, University of Life Sciences in Lublin, B. Dobrzańskiego 3, 20-290 Lublin, Poland
}

Received: 7.07.2009

\begin{abstract}
Ecological traits of Erica carnea L. flowers and the morphology of floral nectaries were investigated using stereoscopic, light and scanning electron microscopy. The nectary in the flowers of Erica carnea is located in the basal part of the ovary. It represents the gynoecial nectary type. It has the form of a yellow, ribbed ring with eight outgrowths, pointed towards the base, which alternately adjoin the stamen filaments. The height of the nectary is $400 \mu \mathrm{m}$ and its thickness $200-250 \mu \mathrm{m}$. The parenchyma of the nectary is composed of $6-8$ layers. Nectar secretion occurs through anomocytic stomata with a diameter of $17 \mu \mathrm{m}$. Guard cells are only found on the outgrowths of the nectary and they are situated most frequently at the level of other epidermal cells. During nectar secretion, a small degree of pore opening was observed. In the flowers of Erica carnea, secondary nectar presentation was found, with the nectar accumulating at the base of the fused corolla.
\end{abstract}

Key words: Erica carnea, floral nectary, position, size, micromorphology

\section{INTRODUCTION}

In the Ericaceae family, different flower structures are found. These flowers differ from one another in their symmetry, the number of elements in particular whorls (4 or 5) and the position of the ovary in the flower (inferior or superior). The position and structure of the nectary are related to the structure of the pistil in this family (B e r n a rde 110,2007$)$.

Heath (Erica) flowers are bisexual, 4 - petalled, with colourful corollas. They occur in small racemose inflorescences at the stem tips. The corolla is gamopetalous, bell- or cup-shaped. Two whorls are distinguished in the androecium composed of 8 stamens. The pistil with superior ovary has a long style. The perianth persists in petal-shedding flowers, where it dries up and surrounds the forming fruit. The fruit is a capsule which contains numerous tiny seeds ( $\mathrm{Hegi}, 1959$; S zwe y kow s c y, 2003; C ze kal ski, 2008).

Erica carnea L. has flowers with pink, light carmine or white corollas forming short hanging racemes. It flowers from March to May. Evergreen leaves are $8 \mathrm{~mm}$ long; they are needle-like, dark green and are borne in whorls of four. Erica carnea L. is native to the mountainous areas of South and Central Europe. This is a plant very frequently grown in gardens. Representatives of this species are clumped shrublets, reaching a height of $20-50 \mathrm{~cm}(\mathrm{P} \mathrm{od} \mathrm{bi} \mathrm{e} \mathrm{l} \mathrm{k} \mathrm{ow} \mathrm{ski} \mathrm{and} \mathrm{S} \mathrm{u} \mathrm{d-}$ nik-Wójcikowska, 2003; S zweykow scy, 2003; C h o jn ow s c y, 2008).

According to S m e t s (1986), the floral nectaries found in Ericaceae form a disc covering the nectary surface and they are included in nectaria persistentia. Maurizio and Grafl (1969) describe the nectaries of Erica as a ring, which has 8 outgrowths pointed downwards, surrounding the superior ovary. On the other hand, B e rnardello (2007) defines the nectaria in Ericaceae as intrastaminal. The nectaries located on the surface of the basal part of the ovary are also found in other representatives of Ericaceae, belonging to the genus Rhododendron (We r y s zko-Chmielewska and Chwil, 2005, 2007; Weryszko-Chmielewska et al. 2003, 2007; Chwil and Weryszko-Chmielewska, 2009).

The aim of the present study was to determine the size and micromorphology of floral nectaries of Erica carnea L., the structure of which has not been examined sufficiently to date.

\section{MATERIALS AND METHODS}

The study of flowers of Erica carnea L. = Erica herbacea L. was conducted in the years 2007-2008, in the Botanical Garden of the Maria Curie-Skłodowska 
University in Lublin. Flowers were sampled at the full bloom stage of the studied shrublets. Ecological traits of flowers and the morphology of floral nectaries were determined using stereoscopic, light and scanning electron microscopy (SEM).

Under a light microscope in cross section, the nectariferous tissues were analysed and the number of nectar-secreting cells was determined. The height and diameter of the ovary and nectary were measured, as well as the distance between the hook-like outgrowths of the nectariferous tissue. The position and type of the floral nectary were determined.

The plant samples used for SEM observation of the structure of the epidermis covering the nectary were fixed in buffered glutaraldehyde. After dehydrating in acetone and critical-point drying in liquid $\mathrm{CO}_{2}$, they were coated with gold using a Sputter Coater. Under a scanning electron microscope TESLA BS-300, the following traits were analysed: the shape of cells of the nectariferous epidermis and cuticular ornamentation as well as the topography and type of stomata.

\section{RESULTS}

\section{Flower morphology}

The attractiveness of Erica carnea flowers is determined by their pink corolla petals and dark purple anthers protruding beyond the ampoule-shaped corolla (Figs 1A, B). Xeromorphic features occurring in Erica carnea are manifested not only in its leaf structure, but also in flower morphology. Both sepals and petals are slightly leathery and they persist for a long time on the plant. The corolla is $4-5 \mathrm{~mm}$ long and it is twice longer than the sepals (Fig. 1B).

The lower parts of the long stamen filaments adjoin the depressions in the basal part of the cylindrical ovary of the pistil, in which the nectary gland is located (Figs 1C, D). The nectary is distinguished by its orange-yellow colour and it has the form of a ribbed ring with hook-like outgrowths. The stamen filaments are arranged alternately relative to the protrusions of the nectary (Figs 1C-E, G). Nectar secretion occurs in the basal part of the nectary (Fig. 1F).

\section{Nectary micromorphology}

The floral nectary of Erica carnea L. forms a protrusion covering about $1 / 4$ of the height of the nectary (Figs $2 \mathrm{~A}-\mathrm{D})$. Eight ribs terminating in hook-like outgrowths at the bottom can be distinguished in it (Figs 1E, D, 2A $-\mathrm{D})$. These outgrowths are arranged alternately with the stamens adjoining the depressed parts of the nectary. The height of the ovary in Erica carnea is $1.6-1.7 \mathrm{~mm}$, and the diameter in the region where the nectary occurs is 0.9 $-1 \mathrm{~mm}$. The nectary ring is about $400 \mu \mathrm{m}$ in height, and its thickness reaches $200-250 \mu \mathrm{m}$ (Tab. 1).
The stomata are only located on the surface of the hook-like outgrowths (Figs 3A, B), whereas the remaining part of the nectary epidermis is devoid of stomata. They occur most frequently at the level of the other epidermal cells (Figs 3C, D). Only some of them are situated on small protuberances (Figs 4A, D). The stomata are formed singly or in twos next to each other (Figs 3B, D). When viewed from above, they have a circular shape (a $17 \mu \mathrm{m}$ diameter) and they are surrounded by $7-8$ epidermal cells. They are included in the anomocytic type. The surface of the epidermis is covered by a smooth cuticle layer. The cuticle forming fine striae is only found on the walls of the guard cells.

Parenchyma cells of the nectary were composed of $6-8$ layers. The colour of the nectary results from the presence of chromoplasts in their protoplasts.

During nectar secretion, a small degree of pore opening was observed in most of the stomata of the nectary epidermis (Figs 3A-D). Small outer cuticular ledges occur around the pores. In the slides viewed under a scanning electron microscope, traces of dried secretion were observed on the surface of the stomata or in their vicinity (Figs 3B, D). The nectar flowing from the downward-pointed outgrowths of the nectary (Fig. 4D) accumulated in the lower part of the corolla tube, from where it was collected by insects. Therefore, it can be stated that secondary nectar presentation occurs in this species.

\section{DISCUSSION}

In the present paper, the micromorphology of the nectary of Erica carnea is presented for the first time. Due to its position in the flower, it is included in gynoecial nectaries associated with the base of the ovary. This nectary has the form of a ribbed ring with outgrowths pointed towards the pedicle. The position of the nectary on the ovary surface shows that the definition of S mets (1986) as well as of Maurizio and Grafl (1969), who describe it as a disc covering the ovary base, is right with regard to the nectary found in Erica flowers. But the definition of B e $\mathrm{r} n$ a r d e 11 o (2007), who finds that the intrastaminal receptacular nectary occurs in Ericaceae, does not seem to be appropriate with respect to this genus.

Anders on et al. (2000) showed that in Pernettya rigida (Ericaceae) the nectary formed 10 outgrowths located between the superior ovary and the corolla. These outgrowths occurred alternately with the stamen filaments.

Freitas et al. (2006) described nectaries in other Ericaceae representatives. In several Gaultheria species, interstaminal nectaries occurred. They observed a ten - segmented nectary around the ovary base in Agarista. The nectary gland in the form of a ring 
Table 1

Characteristics of the ovary and nectary in Erica carnea flowers.

\begin{tabular}{|c|c|c|c|c|c|}
\hline \multicolumn{6}{|c|}{ Investigated trait } \\
\hline \multirow{3}{*}{ Ovary } & \multicolumn{3}{|c|}{ length } & \multirow{3}{*}{$\mathrm{mm}$} & $1.6-1.7$ \\
\hline & \multirow{2}{*}{ diameter } & \multicolumn{2}{|c|}{ at half-length } & & $0.80-0.85$ \\
\hline & & \multicolumn{2}{|c|}{ in the part with the nectary } & & $0.95-1.00$ \\
\hline \multirow{14}{*}{ Nectary } & \multicolumn{3}{|c|}{ height } & \multirow{5}{*}{$\mu \mathrm{m}$} & 400 \\
\hline & \multirow{4}{*}{$\begin{array}{l}\text { thickness of the } \\
\text { nectariferous tissue }\end{array}$} & \multirow{2}{*}{ by the protrusions } & $\min -\max$ & & $230-290$ \\
\hline & & & average & & 250 \\
\hline & & \multirow{2}{*}{ in the depressions } & $\min -\max$ & & $190-211$ \\
\hline & & & average & & 200 \\
\hline & \multicolumn{3}{|c|}{ number of hook-like outgrowths } & & 8 \\
\hline & \multirow{2}{*}{\multicolumn{2}{|c|}{ distance between outgrowths }} & $\min -\max$ & \multirow{2}{*}{$\mu \mathrm{m}$} & $131-190$ \\
\hline & & & average & & 165 \\
\hline & number of the necta & enchyma layers & & & $6-8$ \\
\hline & & diameter & $\min -\max$ & & $15-19$ \\
\hline & & & average & $\mu п$ & 16.8 \\
\hline & stomata & number on the surf & an outgrowth & & $8-10$ \\
\hline & & type & & & anomocytic \\
\hline & & position & & & $\begin{array}{l}\text { apical region of } \\
\text { hook-like outgrowths }\end{array}$ \\
\hline
\end{tabular}

at the ovary base with distinct ribbing has been found in several Rhododendron species (W e r y s z k oChmielewska and Chwil, 2005, 2007; Weryszko-Chmielewska et al. 2007; Chwil and Wery szko-Chmi elew ska, 2009).

Our study showed that nectar secretion in Erica carnea occurred through few stomata which were only located in the basal part of the nectary in the region of the hook-like outgrowths. But in the nectaries of several species of the genus Rhododendron, the occurrence of stomata was found on the whole surface of the nectary. They were located singly or in different clusters (W e ry s z k o- Ch mi e lew ska and Chwil, 2005, 2007; Weryszko-Chmielewska et al. 2007). On the other hand, no stomata at all were found in the epidermis of the floral nectary of Parnettya (A nd e r s o n et al. 2000). The authors think that in this case nectar must be exuded through the rugged cuticle of the nectary.
In the epidermis of the Erica carnea nectary, most of the stomata were located at the level of other epidermal cells. But in plants of the genus Rhododendron, we have shown that these stomata are often elevated above the surface of the nectary (W e ry s zk o-Chmielew ska and Chwil, 2005; 2007). Similarly like in Erica carnea, we have observed anomocytic stomata in the nectaries of Rhododendron ( W e ry s zk o-Ch mi e lew s ka et al. 2007).

The nectary of Erica carnea is yellow-coloured, which results from the presence of chromoplasts. Chromoplasts in parenchyma cells of the nectary have been also observed in species from other botanical families, among others in Chamaelaucium uncinatum (O ' B r e i n, 1996) and Nicotiana tabacum (Thonburg, 2007). 

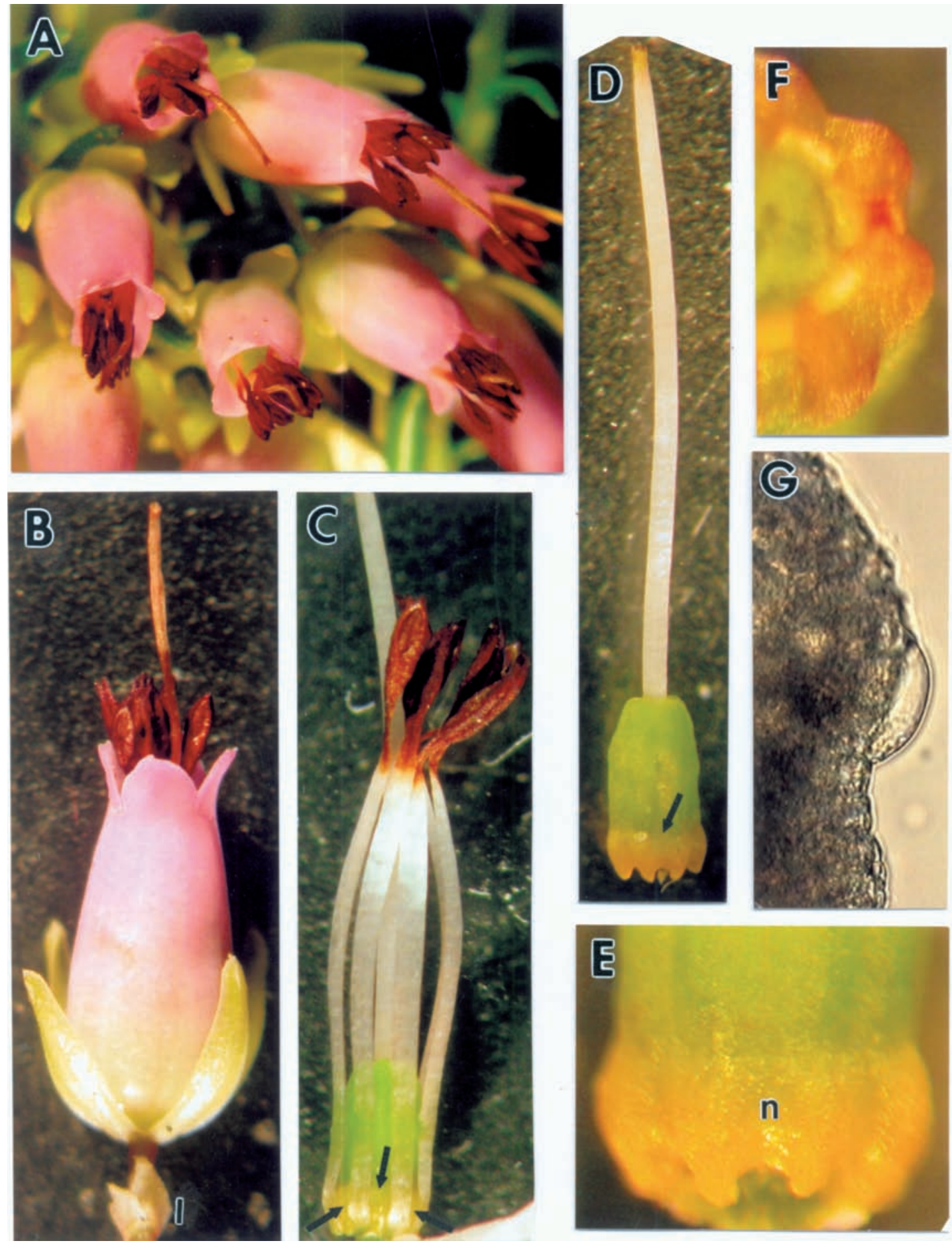

Fig. 1. Erica carnea flowers and their portions.

A - Portion of an inflorescence, $\mathrm{x} 7$.

B - Flower with bracts (1), x 13.

C-Generative elements of a flower after exposing the corolla; between the lower portions of the filaments, protrusions of the nectary are visible (arrows), x 16.

D - Pistil with a green ovary and yellow nectary (arrow) at the ovary base, $\mathrm{x} 16$.

E - Lower part of the ovary with the nectary (n), x 512.

$\mathrm{F}$ - Outgrowths of the nectary viewed from the side of the pedicle, $\mathrm{x} 230$.

$\mathrm{G}-$ Nectar droplet on the nectary surface, $\mathrm{x} 390$. 
Table 2

Comparison of nectary morphology in several plant species of the family Ericaceae.

\begin{tabular}{|c|c|c|c|c|c|c|}
\hline \multirow{2}{*}{ Species } & \multicolumn{2}{|r|}{ Nectary } & \multicolumn{2}{|c|}{ Stomata } & \multirow{2}{*}{$\begin{array}{l}\text { Nectar } \\
\text { exuded } \\
\text { through }\end{array}$} & \multirow{2}{*}{ Autor } \\
\hline & type & located & type & distributed & & \\
\hline $\begin{array}{l}\text { Agarista } \\
\text { hispidula }\end{array}$ & \multirow[t]{2}{*}{ inter-staminal } & \multirow[t]{2}{*}{$\begin{array}{l}10 \text { segmented around the } \\
\text { ovary base }\end{array}$} & \multirow{2}{*}{\multicolumn{2}{|c|}{-}} & \multirow[t]{2}{*}{-} & \multirow[t]{2}{*}{$\begin{array}{l}\text { Freitas et al. } \\
\text { (2006) }\end{array}$} \\
\hline A. oleifolia & & & & & & \\
\hline Erica carnea & gynoecial & $\begin{array}{l}\text { a ribbed ring at the base } \\
\text { part of the ovary }\end{array}$ & anomocytic & $\begin{array}{l}\text { singly or in } \\
\text { twos }\end{array}$ & stomata & $\begin{array}{l}\text { Results in the } \\
\text { present paper }\end{array}$ \\
\hline $\begin{array}{l}\text { Gaultheria } \\
\text { sleumeriana }\end{array}$ & \multirow{2}{*}{ inter-staminal } & $\begin{array}{l}\text { projections around the } \\
\text { ovary base }\end{array}$ & \multicolumn{2}{|r|}{-} & & \multirow{2}{*}{$\begin{array}{l}\text { Freitas et al. } \\
(2006)\end{array}$} \\
\hline $\begin{array}{l}\text { Gaylussacia } \\
\text { chamissonis }\end{array}$ & & $\begin{array}{l}\text { around the style over the } \\
\text { ovary }\end{array}$ & \multicolumn{2}{|r|}{-} & & \\
\hline $\begin{array}{l}\text { Pernettya } \\
\text { rigida }\end{array}$ & receptacular & $\begin{array}{l}10 \text { outgrowths occurred } \\
\text { alternately with the } \\
\text { stamen filaments, } \\
\text { between the superior } \\
\text { ovary and the corolla }\end{array}$ & \multicolumn{2}{|c|}{-} & $\begin{array}{l}\text { through } \\
\text { the rugged } \\
\text { cuticle }\end{array}$ & $\begin{array}{l}\text { Anderson et al. } \\
(2000)\end{array}$ \\
\hline $\begin{array}{l}\text { Rhododendron } \\
\text { catawbiense }\end{array}$ & gynoecial & $\begin{array}{l}\text { at the base of the ovary, } \\
\text { ribbing nectary }\end{array}$ & anomocytic & $\begin{array}{l}\text { singly quite } \\
\text { evenly }\end{array}$ & stomata & $\begin{array}{l}\text { Weryszko-Chmie- } \\
\text { lewska et al. } \\
(2007)\end{array}$ \\
\hline R. japonicum & gynoecial & at the base of the ovary & $\begin{array}{l}\text { actinocytic; } \\
\text { compact } \\
\text { stomata } \\
\text { fields }\end{array}$ & $\begin{array}{l}\text { singly } \\
\text { and stomata } \\
\text { fields }\end{array}$ & stomata & $\begin{array}{l}\text { Weryszko-Chmie- } \\
\text { lewska and Chwil } \\
(2007)\end{array}$ \\
\hline R. luteum & gynoecial & $\begin{array}{l}\text { a bulge at the basal part of } \\
\text { the ovary }\end{array}$ & anomocytic & $\begin{array}{l}\text { singly and } \\
\text { evenly }\end{array}$ & stomata & $\begin{array}{l}\text { Weryszko-Chmie- } \\
\text { lewska and Chwil } \\
(2005)\end{array}$ \\
\hline
\end{tabular}

\section{CONCLUSIONS}

1. The nectary in the flowers of Erica carnea is located in the basal part of the ovary and it represents the gynoecial nectary type.
2. Nectar secretion occurs through the stomata situated only in the apical parts of the outgrowths of the nectary. 

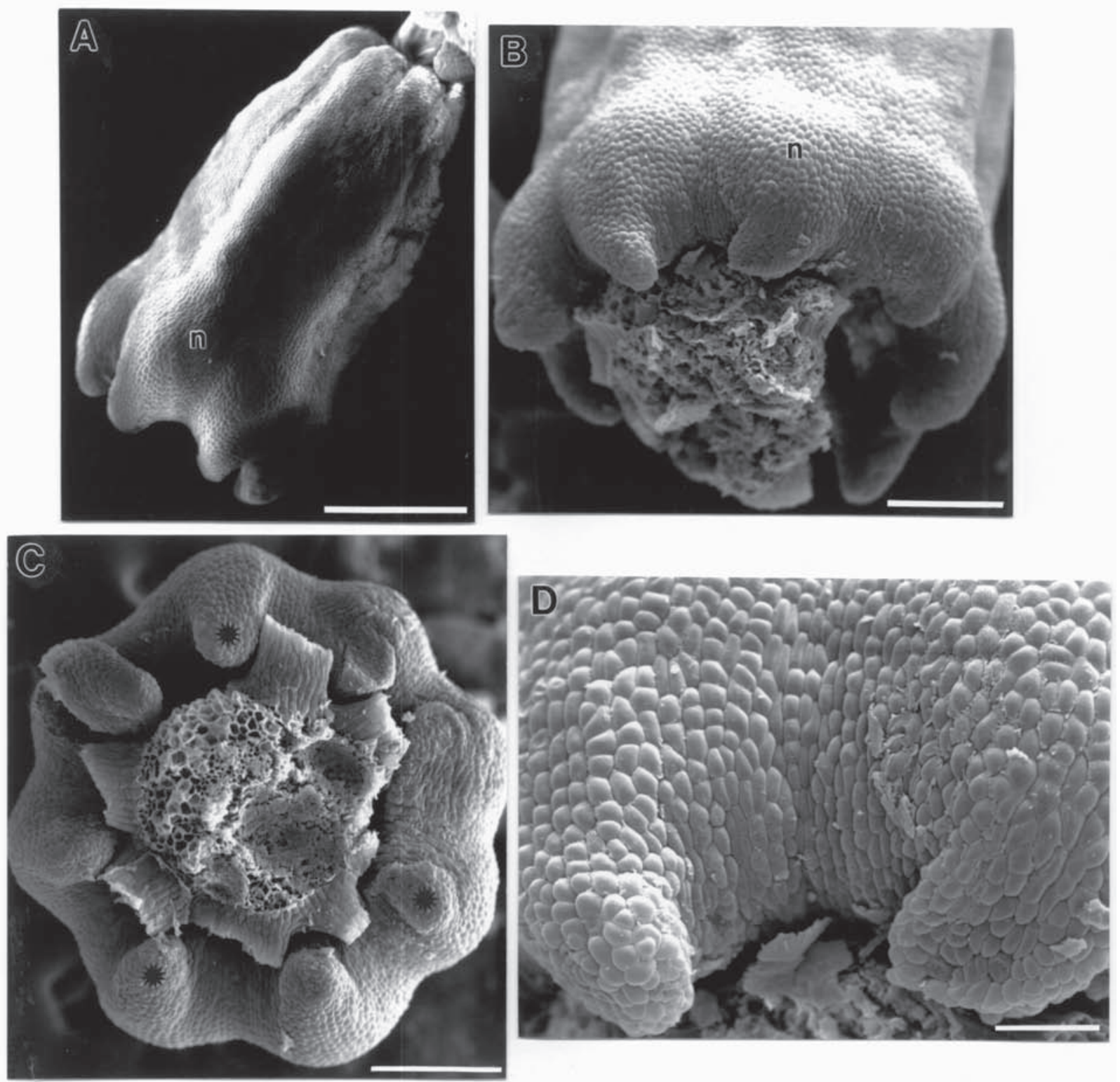

Fig. 2. Erica carnea ovary with the nectary (SEM).

A - Elongated ovary with the nectary ( $\mathrm{n}$ ) at the base, bar $=500 \mu \mathrm{m}$.

B - Nectary (n) forming a ring-like protrusion on the ovary, bar $=200 \mu \mathrm{m}$.

$\mathrm{C}$ - Hook-like outgrowths of the nectary (asterisks) viewed from the side of the pedicle, $b a r=200 \mu \mathrm{m}$.

D - Basal part of the nectary with outgrowths, bar $=90 \mu \mathrm{m}$. 

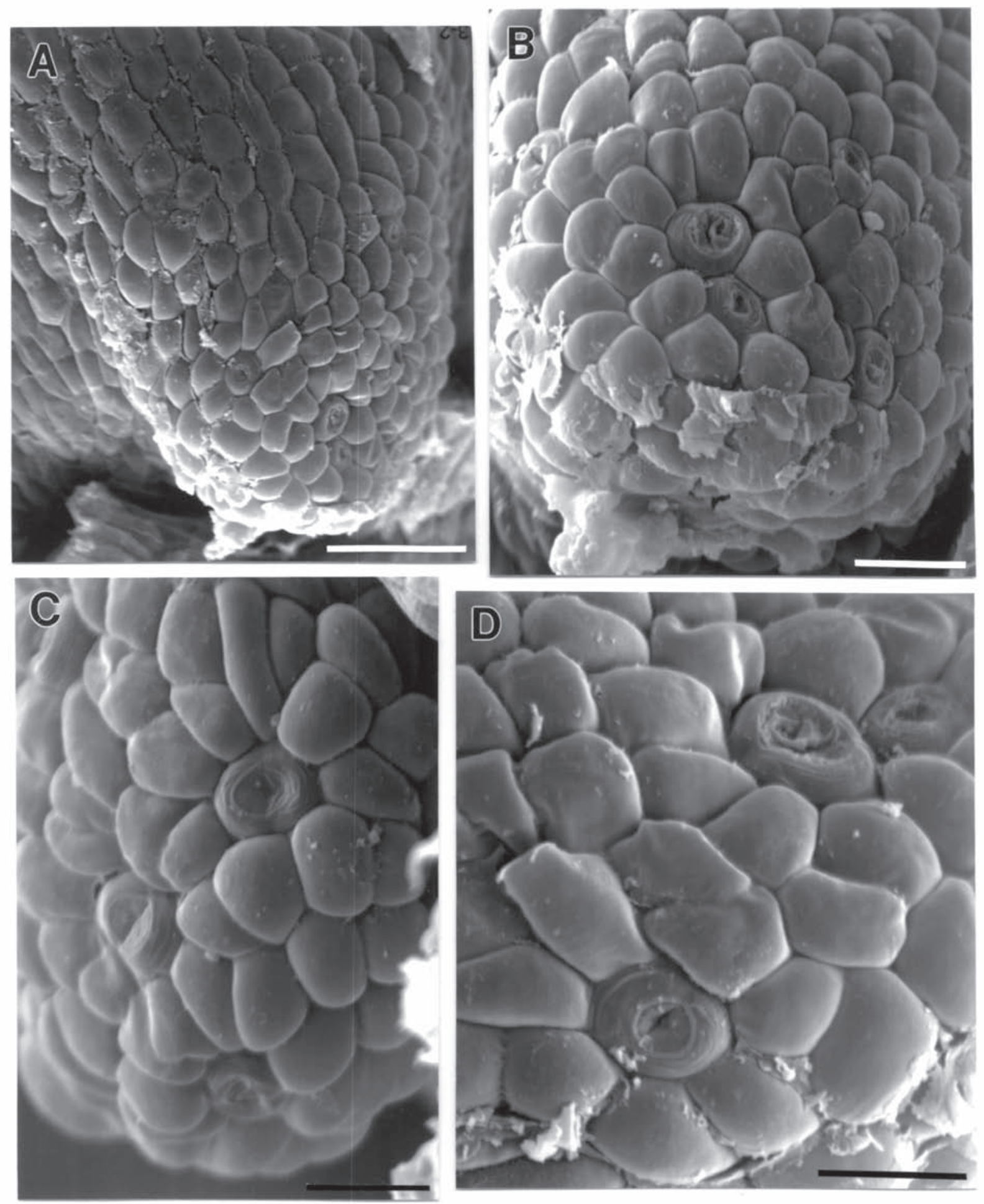

Fig. 3. Portions of the surface of the Erica carnea nectary (SEM)

A, B - Isodiametrical epidermal cells and stomata in the apical region of the hook-like outgrowths, A-bar $=60 \mu \mathrm{m}, \mathrm{B}-\mathrm{bar}$ $=30 \mu \mathrm{m}$.

A, B, D - Visible traces of dried secretion

C, D - Anomocytic stomata of the nectary, bars $=20 \mu \mathrm{m}$. 


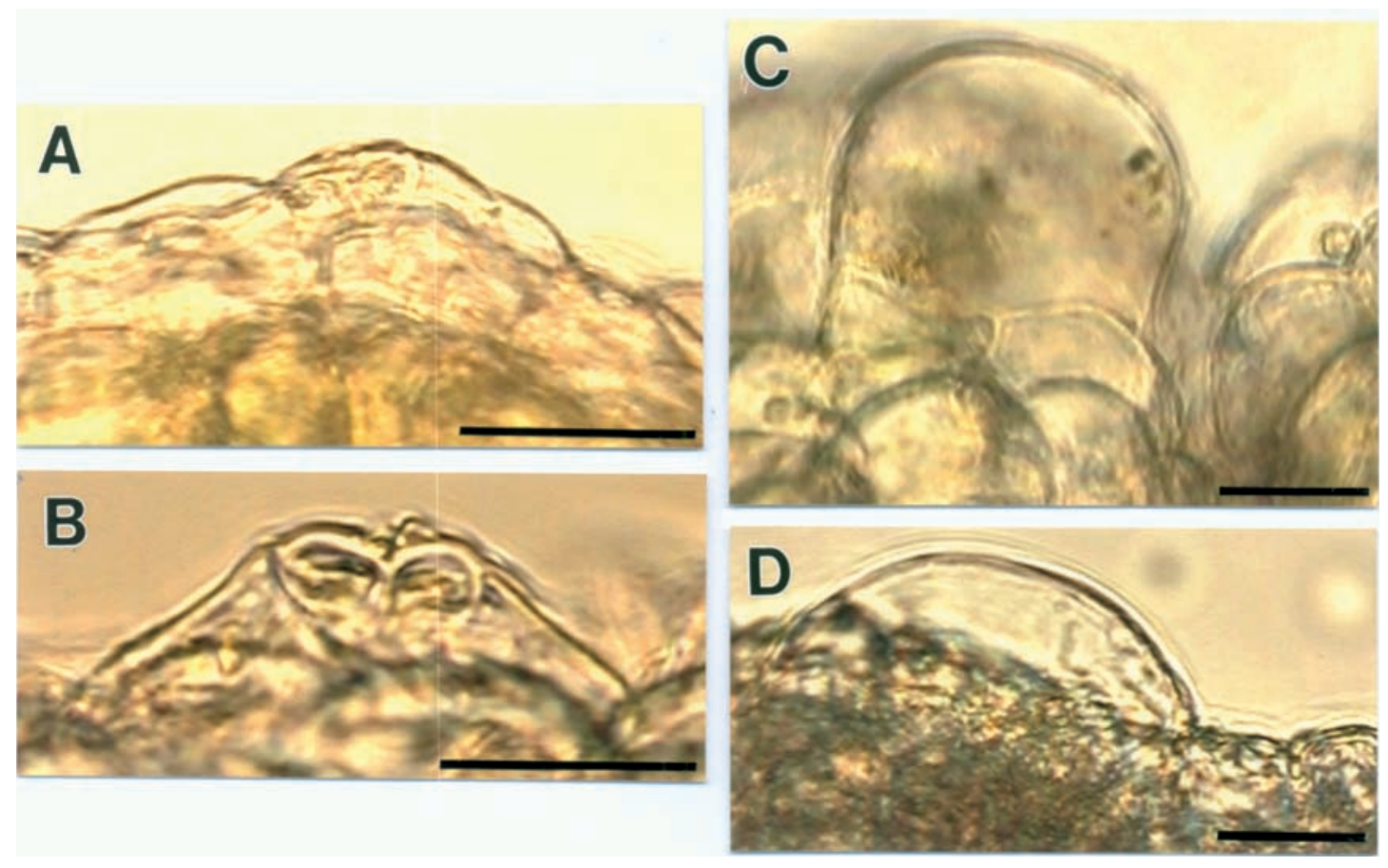

Fig. 4. Stomata and nectar on the surface of the Erica carnea nectary (LM).

A - Stoma located at the level of other epidermal cells, bar $=30 \mu \mathrm{m}$.

B - Stoma situated on a small protuberance, $b a r=20 \mu \mathrm{m}$.

C, D - Nectar droplets flowing out of stomata, bars $=20 \mu \mathrm{m}$.

\section{REFERENCES}

Anders on G. J., 2000. Dioecy and wind pollination in Pernettya rigida (Ericaceae) of the Juan Fernández Islands. Bot. J. Linnean Society, 132: 121-141.

Bernarde11o G., 2007. A systematic survey of floral nectaries. [In:] Nectaries and nectar. Nicolson S. W., Nepi M., Pacini E. (eds). Springer, Dordrecht: 19-128.

Chojnowscy E. M., 2008. Azalie, różaneczniki, wrzosy i inne wrzosowate. Multico Oficyna Wydawnicza, Warszawa.

Czekalski M., 2008. Wrzosy, wrzośce i inne rośliny wrzosowate. Państwowe Wydawnictwo Rolnicze i Leśne, Poznań.

Chwil M., Weryszko-Chmielewska E., 2009. Characteristics of nectaries and nectar in flowers of two Rhododendron species. J. Apic. Sci. 53 (1): 17-27.

Freitas L., Galetto L., Sazima M., 2006. Pollination by hummingbirds and bees in eight syntopic species and a putative hybrid of Ericaceae in Southeastern Brazil. Pl. Syst. Evol. 258: 49-61.

Hegi G., 1959. Illustrierte Flora von Mittel-Europa. Mit besonderer Berücksichtigung von Doutschland, Österrieich and der Schweiz. Carl Hanser, Verlag, München.
Maurizio A., Grafl I., 1969. Das Trachtplanzenbuch. Ehrenwirth Verlag, München.

O' B rie n S. P., L oveys B. R., Grant W. J. R., 1996. Ultrastructure and function of floral nectaries of Chamelaucium uncinatum (Myrtaceae). Ann. Bot. 78: 189-196.

Podbielkowski Z., Sudnik-Wójcikowska B., 2003. Słownik roślin użytkowych. Państwowe Wydawnictwo Rolnicze i Leśne, Warszawa.

S met s E., 1986. Localization and systematic importance of the floral nectaries in the Magnoliatae (Dicotyledons). Bull. Jard. Bot. Nat. Belg. 56: 51-76.

Szweykowscy A. J., 2003. Słownik botaniczny. Warszawa.

Thornburg R. W., 2007. Molecular biology of the Nicotiana floral nectary. [In:] Nectaries and nectar. Nicolson S. W., Nepi M., Pacini E. (eds). Springer, Dordrecht: 265288.

Weryszko-Chmielewska E., Chwil M., 2005. Morphological features of the nectary and of the pollen grains and the foraging value of the flowers of yellow azalea (Rhododendron luteum Sweet). J. Apic. Sci. 49 (2): 5-12.

Weryszko-Chmielewska E., Chwil M., 2007. Micromorphology of the epidermis of the floral nectary of 
Rhododendron japonicum (A. Gray) J. V. Suringar ex E. H. Wilson. Acta Agrobot. 60 (1): 45-53.

Weryszko-Chmielewska E., Chwil M., Michońsk a M., 2007. Micromorphology of nectaries of Rhododendron catawbiense Michx. at different flower development stages. Acta Agrobot. 60 (2): 15-22.

Weryszko-Chmielewska E., Sawidis T., Matusiewicz J., 2003. Przystosowania ekologiczne kwiatów różanecznika żółtego (Rhododendron luteum Sweet) z uwzględnieniem struktury nektarnika. / Ecological adaptations of flowers of yellow azalea (Rhododendron luteum Sweet), including the nectary structure. Ann. Univ. Mariae Curie-Skłodowska, Sect. EEE, Hortic. 13: 17-21.

\section{Localization and structure of nectary in spring heath (Erica carnea $\mathbf{L}$.) flowers}

\section{Streszczenie}

Cechy ekologiczne kwiatów Erica carnea L. i morfologię nektarników kwiatowych badano przy użyciu mikroskopii: stereoskopowej, świetlnej i skaningowej elektronowej. Nektarnik w kwiatach Erica carnea położony jest w bazalnej części zalążni. Prezentuje typ genoecial nectary. Ma postać żółtego, żebrowanego pierścienia ze skierowanymi ku nasadzie ośmioma wyrostkami, które międzylegle przylegają do nitek pręcików. Wysokość nektarnika wynosi $400 \mu \mathrm{m}$, a miąższość $200-250 \mu \mathrm{m}$. Parenchyma nektarnika tworzy $6-8$ warstw. Sekrecja nektaru odbywa się przez anomocytyczne aparaty szparkowe o średnicy $17 \mu \mathrm{m}$. Komórki szparkowe występują tylko na wyrostkach nektarnika i są usytuowane najczęściej na poziomie innych komórek epidermy. Podczas sekrecji nektaru obserwowano niewielki stopień rozchylenia szparek. W kwiatach Erica carnea stwierdzono wtórną prezentację nektaru, który gromadził się u nasady zrośniętej korony. 
